\title{
Community electron transport of procaryotes in euryoxic estuarine sediment
}

\author{
Ernest A. Matson*, John D. Buck \\ Marine Research Laboratory, University of Connecticut, Noank, Connecticut 06340, USA
}

\begin{abstract}
Rates of both tetrazolium and oxygen reduction were obtained seasonally from the top 8 $\mathrm{cm}$ of euryoxic estuarine sediment in southeastern New England, USA, over an in situ temperature range of 0 to $20^{\circ} \mathrm{C}$. Anoxic tetrazolium reduction was highest in the 3 to $5 \mathrm{~cm}$ layers at $15^{\circ} \mathrm{C}$ (up to 860 nmol $\left.2 \mathrm{e}^{-} \mathrm{cm}^{-3} \mathrm{~h}^{-1}\right)$. Changes in the chemistry of deeper pore-waters (20 to $60 \mathrm{~cm}$ ) occurring over $90 \mathrm{~d}$ indicated that metabolic rates ( $\mathrm{ca} 42 \mathrm{nmol} 2 \mathrm{e}^{-} \mathrm{cm}^{-3} \mathrm{~h}^{-1}$ ) were about an order of magnitude lower than those in the surface sediments. Parallel simultaneous estimates of $\mathrm{O}_{2}$ reduction (reduced sediment preincubated in $\mathrm{O}_{2}$-saturated ambient waters $\pm 10 \mathrm{mM} \mathrm{NaN}_{3}$ ) averaged 4 times greater than tetrazolium reduction. The postulated occurrence of a mixed metabolic community consisting of facultatively anaerobic heterotrophs and chemolithotrophs agrees with the field data. The community is spread out vertically through watery sediment of a quiescent, highly depositional cove. Soft-bodied infauna may help maintain the Eh potential at ca $-200 \mathrm{mV}$ from 1 to $60 \mathrm{~cm}$; the sediment is not sufficiently cohesive to be strongly poised.
\end{abstract}

\section{INTRODUCTION}

Very high rates of microbial activity have been found in subsurface layers of coastal sediments near the redox discontinuity layer ('reductocline') (Novitsky \& Kepkay 1981, Graf 1986, Novitsky \& Karl 1986, Peroni \& Rossi 1986). A strongly poised reductocline can be maintained by cohesive sediment and by abundant supplies of Fe that sequester reduced S. This transition zone contains a variety of oxidized and reduced organic and inorganic materials that sequentially and alternately function as electron donors and acceptors under a regime of advection, diffusion, and rapid recycling. A diverse assemblage of hetero-, mixo-, and autotrophic microorganisms maintains this electrochemical gradient.

Here we present tetrazolium and oxygen reduction data from euryoxic and anoxic estuarine muds and find subsurface maxima in anoxic activity within the top 8 $\mathrm{cm}$ that decrease about 10 -fold at depths of 50 to $60 \mathrm{~cm}$. However, in contrast with studies cited above, the maxima occur in an electrochemically homogenous milieu. We attribute these higher rates to the existence of a quiescent depositional regime that promotes the

- Present address: Marine Laboratory, University of Guam, Mangilao, Guam 96923 accumulation of watery muds and the subsequent extension of a poorly poised reductocline down to at least $60 \mathrm{~cm}$ in the sediment. Sediment has accumulated at this site up to the critical wave mixing depth (ca $1 \mathrm{~m}$ at $\mathrm{MHW}$ ) so that no new net sedimentation occurs. In this regime, the sediment column is being metabolized from the bottom up, with both methanogens and sulfate-reducers occupying the same levels in top $10 \mathrm{~cm}$ muds (Hines \& Buck 1982).

\section{MATERIALS AND METHODS}

Study area. Quiambog Cove (average depth $=1 \mathrm{~m}$; area $=29 \mathrm{ha}$ ) is a submerged valley located near Stonington, Connecticut $\left(41^{\circ} 25^{\prime} \mathrm{N}, 71^{\circ} 57^{\prime} \mathrm{W}\right)$ in southeastern New England, USA, that contains glacial till and alluvium. The mouth of the estuary is constricted by a railroad bridge constructed about a century ago. Consequently, the cove has rapidly filled with fine sediment to a level where no net sediment accumulation can occur because of turbulence. Similar construction activities have affected many of the drowned stream valleys throughout New England. The flow ratio (13 $\mathrm{h}$ river flow/tidal prism volume) for this cove ranges between 0.006 and 0.9 , but remains less than 0.1 during 8 mo of the year. Average tidal flushing times range 
between 1.9 and $3.4 \mathrm{~d}$ (Foerster 1973). The sediment can be described as muddy clay that only rarely has salinities below $10 \%$. About $20 \%$ of the cove is covered with Zostera marina, and the remainder has various seasonal assemblages of Gracillaria, Lomentaria, Enteromorpha, and Fucus. Annual organic carbon (OC) supply to these sediments ranges from 70 to $170 \mathrm{~mol} \mathrm{~m}^{-2}$ and averages 120 , which includes $45 \mathrm{~mol}$ from terrestrial runoff (Matson 1982).

Sediment and pore-water chemistry. Sixteen porewater samplers (Soil Moisture Samplers ${ }^{\circledR}$ ) were cleaned, installed in the sediments to depths of 20 to 60 $\mathrm{cm}$ at 8 sites in the cove in early March, allowed to leach and equilibrate for $1 \mathrm{mo}$, and sampled in April (at $5^{\circ} \mathrm{C}$ ) and July (at $20^{\circ} \mathrm{C}$ ). Waters were removed in situ by displacing sampler contents with $\mathrm{N}_{2}$ into a $50 \mathrm{~cm}^{3}$ syringe. The waters were immediately analyzed for redox potential ( $\mathrm{Eh}$ ) and $\mathrm{pH}$ (Corning electrodes), and $\mathrm{NH}_{4}^{+}$(phenol/hypochlorite); preserved samples were later analyzed for $\mathrm{Cl}^{-}$(Buchler-Cotlove $\mathrm{Cl}$ titrator), $\mathrm{SO}_{4}^{2-}\left(\mathrm{BaCl}_{2}\right)$, alkalinity (titration), dissolved organic carbon (DOC; thermal combustion, IR detection), and carbohydrates (Gerchakov \& Hatcher 1972). Box cores of the upper 10 to $15 \mathrm{~cm}$ were taken irregularly and were processed the same day for chemical constituents as above.

Tetrazolium and oxygen reduction. Solutions of INT (2-p-iodophenyl-3-p-nitrophenyl-5-phenyl $2 \mathrm{H}$ tetrazolium chloride; Sigma, Grade I) were made up at ca $25 \mathrm{mM}$ in ethyl alcohol (EtOH), stored in acid-cleaned glass vials with Polyseal ${ }^{\circledast}$ caps to prevent evaporation of EtOH and wrapped with black tape to avoid photoreduction. The EtOH solvent did not affect the activity of the samples tested at concentrations less than $10 \%$, and in no case was the final EtOH concentration $>2 \%$. Standard curves were constructed with $\mathrm{N}_{2}$-sparged solutions of either ascorbic acid or $\mathrm{S}^{2-}$ (as $\mathrm{Na}_{2} \mathrm{~S} \cdot 9 \mathrm{H}_{2} \mathrm{O}$; both Fisher Reagent Grade) as reductants. Molar absorptivities $\left(17400 \mathrm{l}^{-1} \mathrm{~mol}^{-1} \mathrm{~cm}^{-1}, \pm 2 \%\right.$ at $\left.465 \mathrm{~nm}\right)$ were identical to those reported by Altman (1976), and all INT added was completely reduced (Matson 1982).

Samples of surface mud were obtained with ordinary manual coring procedures that protected the integrity of the sediment-water interface. All muds were sectioned, subsampled, and processed under $\mathrm{N}_{2}$ in a glove bag and slurried with filtered waters obtained from the coring site. Controls for chemical tetrazolium reduction were immediately autoclaved at $15 \mathrm{psi}\left(=10^{5} \mathrm{~Pa}\right)$ for 30 min in a gas-tight clamp device used to sterilize tubed media for methanogens (Hines \& Buck 1982). Total acid-volatile sulfides ( $\mathrm{TS}^{2-}=\mathrm{HS}^{-}+\mathrm{H}_{2} \mathrm{~S}+\mathrm{FeS}$ ) were measured colorimetrically with either methylene blue (Cline 1969) or INT (Matson 1985). Under $\mathrm{N}_{2}, 60 \mu \mathrm{l}$ of $25 \mathrm{mM}$ INT were added to $3 \mathrm{ml}$ mud slurries to obtain a final optimum concentration of $0.5 \mathrm{mM}$ INT (Matson
1982). Subsamples were incubated at in situ temperatures and were sacrificed after variable periods of up to 300 min depending upon (a) ambient temperature and (b) visual evidence of formazan production.

Reduction of INT in time-series incubations was stopped by filtration and resuspension of the sediment in several volumes of acetone, which extracts the INT-formazan. This extract also provided a blank for photosynthetic pigments (rarely $>10 \%$ of absorbance at 465 $\mathrm{nm})$. Acetone extraction of clastic sediments takes 0.5 to $2 \mathrm{~h}$, sometimes requires clarification by filtration or centrifugation prior to spectrophotometry, and the extract is stable for at least 1 mo in the dark. Among 5 sets of duplicates slurried up to 5 -fold, relative precision was 10 to $15 \%$ (Matson 1982, 1985).

INT reduction requires $2 e^{-}$, and data are expressed as mol $2 \mathrm{e}^{-}$equivalents per unit weight or volume of sediment per unit time. The time units and net biochemical reduction rates were calculated by 2 methods: (1) by subtraction of the 5,10 or $20 \mathrm{~min}$ incubation data (which are mostly due to chemical INT reduction; Matson 1982, 1985, Peroni \& Rossi 1986) from the $30 \mathrm{~min}, 60 \mathrm{~min}$, or longer term incubations (depending on ambient temperature); and (2) by subtraction of autoclaved chemical controls from total tetrazolium reduction.

\section{RESULTS}

\section{Sediment and pore-water chemistry}

The Eh of the top $60 \mathrm{~cm}$ of sediment remained at about $-200 \mathrm{mV}$ in almost all samples between April and July (Table 1, Fig. 1). Pore-water Eh was greater than $-200 \mathrm{mV}$ in only 5 of 16 pore-water samplers in April, and in 1 of 15 in July. Sediment (Fig. 1) and porewater (Table 1) $\mathrm{pH}$ varied slightly, remaining between 6.6 and 7.8. Both surface sediment and deeper pore waters showed evidence of freshwater intrusion, especially at sites nearer the head of the estuary (Stns QC7 to 9). $\mathrm{SO}_{4}^{2-}$ was slightly enriched in the warmed surface sediments in early June (Fig. 1), and was depleted by up to $100 \%$ in the pore-water samplers. In April, DOC and ammonium levels were quite high, and by July, when the sediments had warmed to $20^{\circ} \mathrm{C}$, alkalinities increased substantially with a corresponding decrease in DOC. DOC values ranged from a low of $1.5 \mathrm{mM}$ in July to a high of $30 \mathrm{mM}$ in April. Total carbohydrates were a minor fraction of the total DOC pool, and ranged from 0.008 to $0.056 \mathrm{mM}$.

In April, when the sediments were still cold from winter, these metabolites were strongly related, with linear regression coefficients $>0.82$ (Fig. 2). Later in July, the data were not as well related. Alkalinity 
Table 1. Quiambog Cove pore-water chemistry. Z: depth; T.A.: titration alkalinity; sulfate data are percent depletion from seawater stoichiometry expected at in situ $\mathrm{Cl}^{-} ; \mathrm{CH}_{2} \mathrm{O}$ is glucose equivalents. 'Samplers left undisturbed and resampled in July. Station numbers decrease towards the mouth of the estuary, and stations QCZ are located between Stns 4 and 7

\begin{tabular}{|c|c|c|c|c|c|c|c|c|c|}
\hline Station & $\begin{array}{c}\mathrm{Z} \\
(\mathrm{cm})\end{array}$ & $\begin{array}{l}\text { Eh } \\
(\mathrm{mV})\end{array}$ & $\mathrm{pH}$ & $\begin{array}{c}\mathrm{Cl}^{-} \\
(\mathrm{mM})\end{array}$ & $\begin{array}{c}\text { T.A. } \\
\left(\text { meq } 1^{-1}\right)\end{array}$ & $\% \mathrm{SO}_{4}^{2-}$ & $\begin{array}{l}\text { DOC } \\
(\mathrm{mM})\end{array}$ & $\begin{array}{l}\mathrm{NH}_{4}^{+} \\
(\mathrm{mM})\end{array}$ & $\begin{array}{l}\mathrm{CH}_{2} \mathrm{O} \\
(\mathrm{mM})\end{array}$ \\
\hline \multicolumn{10}{|l|}{ April, $5^{\circ} \mathrm{C}$} \\
\hline$Q C-2 S$ & 26 & -210 & 7.3 & 460 & 6.6 & 17 & 8.1 & 0.24 & 0.022 \\
\hline $\mathrm{QC}-3 \mathrm{~S}$ & 26 & -220 & 7.5 & 470 & 9.1 & 50 & 22 & 0.50 & 0.031 \\
\hline $\mathrm{QC4}-\mathrm{S} 1$ & 29 & -220 & 7.8 & 460 & 12 & 54 & 22 & 1.5 & 0.014 \\
\hline $\mathrm{QC4}-\mathrm{S} 2$ & 29 & -220 & 7.7 & 450 & - & 58 & 24 & 0.70 & 0.021 \\
\hline$Q C Z-1 S$ & 26 & -220 & 7.4 & 400 & 11 & 38 & 17 & 0.45 & 0.039 \\
\hline$Q C Z-2 S$ & 29 & -160 & 7.5 & 360 & 4.8 & 47 & 15 & 0.60 & 0.008 \\
\hline QC7-S & 17 & -200 & 7.8 & 360 & 6.8 & 50 & 16 & 0.35 & 0.056 \\
\hline $\mathrm{QC} 8-\mathrm{S} 1$ & 9 & +60 & 7.4 & 150 & 2.9 & 98 & 5.1 & 0.20 & 0.014 \\
\hline QC8-S2 & 27 & -110 & 7.3 & 330 & 4.2 & 29 & 5.0 & 0.16 & 0.012 \\
\hline QC9-S & 30 & +60 & 7.1 & 260 & 4.3 & 42 & 5.4 & 0.15 & 0.005 \\
\hline $\mathrm{QC} 2-\mathrm{L}$ & 50 & -100 & 7.4 & 460 & 9.0 & 29 & 8.5 & 0.28 & 0.016 \\
\hline QC3-L & 57 & -220 & 7.7 & 480 & 22 & 75 & 30 & 1.0 & 0.005 \\
\hline $\mathrm{QCZ}-\mathrm{L1}$ & 57 & -220 & 7.6 & 320 & 12 & 98 & 28 & 0.90 & 0.047 \\
\hline $\mathrm{QCZ}-\mathrm{I} 2$ & 51 & -220 & 7.8 & 310 & 16 & 86 & 20 & 0.90 & 0.017 \\
\hline $\mathrm{QC7}-\mathrm{L}$ & 51 & -220 & 7.8 & 260 & 10 & 96 & 20 & 0.50 & 0.010 \\
\hline QC9-L & 55 & +90 & 7.4 & 110 & 4.2 & 91 & 4.9 & 0.26 & - \\
\hline \multicolumn{10}{|l|}{ July, $20^{\circ} \mathrm{C}$} \\
\hline - $\mathrm{QC} 4-S 1$ & 29 & -210 & 7.4 & 470 & 23 & 45 & 3.3 & \multicolumn{2}{|c|}{ No July data } \\
\hline QC5-S & 27 & -210 & 7.3 & 510 & 39 & 80 & 3.8 & & \\
\hline$\cdot \mathrm{QC} 7-\mathrm{S}$ & 17 & -210 & 6.9 & 370 & 24 & 55 & 3.3 & & \\
\hline $\mathrm{QC} 8-\mathrm{S} 1$ & 27 & -210 & 6.9 & 340 & 64 & 29 & 3.0 & & \\
\hline$\cdot \mathrm{QC} 8-\mathrm{S} 2$ & 27 & -210 & 7.0 & 370 & 72 & 16 & 2.0 & & \\
\hline QC9-S & 30 & -210 & 7.0 & 270 & 84 & 32 & 2.5 & & \\
\hline$\cdot \mathrm{QCZ}-\mathrm{S} 1$ & 26 & -210 & 7.5 & 420 & 22 & 57 & 3.4 & & \\
\hline${ }^{\circ} \mathrm{QCZ}-\mathrm{S} 2$ & 29 & -210 & 7.3 & 390 & 32 & 55 & 3.1 & & \\
\hline $\mathrm{QCZ}-\mathrm{S} 3$ & 30 & -210 & 7.2 & 450 & 20 & 44 & 4.1 & & \\
\hline QC6-L & 55 & -150 & 6.7 & 480 & 3.7 & 16 & 1.5 & & \\
\hline QC8-L & 55 & -210 & 7.4 & 170 & 47 & 74 & 1.5 & & \\
\hline$\cdot Q C 9-\bar{L}$ & $5 \overline{5}$ & -210 & 0.0 & 120 & 40 & 49 & 3.1 & & \\
\hline$\cdot{ }^{\circ} \mathrm{QCZ}-\mathrm{L} 1$ & 57 & -210 & 7.3 & 340 & 28 & 100 & 4.8 & & \\
\hline$\cdot \mathrm{QCZ}-\mathrm{L} 2$ & 50 & -210 & 7.2 & 320 & 18 & 67 & 2.9 & & \\
\hline $\mathrm{QCZ}-\mathrm{L} 3$ & 55 & -210 & 7.4 & 450 & 83 & 80 & 7.5 & & \\
\hline
\end{tabular}

values increased dramatically to as high as 84 meq $1^{-1}$, while DOC values decreased ca 1 order of magnitude. In contrast, sulfate depletions (normalized to seawater

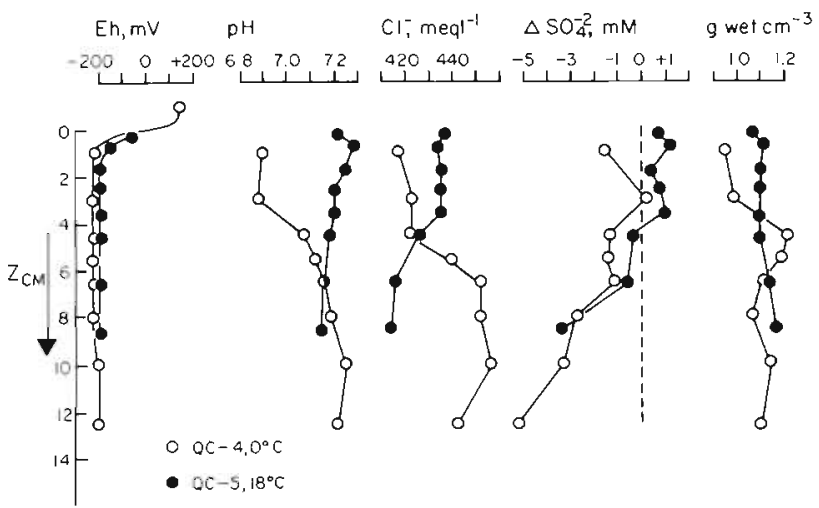

Fig. 1. Quiambog Cove surface sediment chemistry. Redox potential (Eh) and $\mathrm{pH}$ by direct insertion of electrodes into sectioned sediment under $\mathrm{N}_{2}$ i change in $\mathrm{SO}_{4}^{2-}$ concentrations from seawater $\mathrm{Cl}^{-}$stoichiometry, and bulk sediment density
$\mathrm{Cl}^{-}$stoichiometry) changed very little during this $90 \mathrm{~d}$ period.

\section{Tetrazolium and oxygen reduction}

Over the entire range of in situ temperatures tested, anoxic INT reduction ranged from 0 to $860 \mathrm{nmol} 2 \mathrm{e}^{-}(0$ to $430 \mathrm{nmol} \mathrm{O}_{2}$ equivalents) $\mathrm{cm}^{-3} \mathrm{~h}^{-1}$ (Table 2). Subsurface peaks in anoxic INT reduction occurred at all 4 temperatures. Maximum average activity was at $15^{\circ} \mathrm{C}$, and the highest depth average was at ca $5 \mathrm{~cm}$. Biochemical oxygen reduction (distinguished from chemical oxygen demand [COD] with $10 \mathrm{mM} \mathrm{NaN}_{3}$ ] at 15 and $20^{\circ} \mathrm{C}$ ranged from 480 to 2100 . At $15^{\circ} \mathrm{C}$, a minimum in $\mathrm{O}_{2}$ reduction coincided with a maximum in INT reduction, while at $20^{\circ} \mathrm{C}$, the 2 rates showed similar trends. The average $\mathrm{INT} / \mathrm{O}_{2}$ reduction rate ratios were 0.67 and $0.22 \mathrm{nmol} 2 \mathrm{e}^{-} \mathrm{cm}^{-3} \mathrm{~h}^{-1}$ at 15 and $20^{\circ} \mathrm{C}$, respectively. 


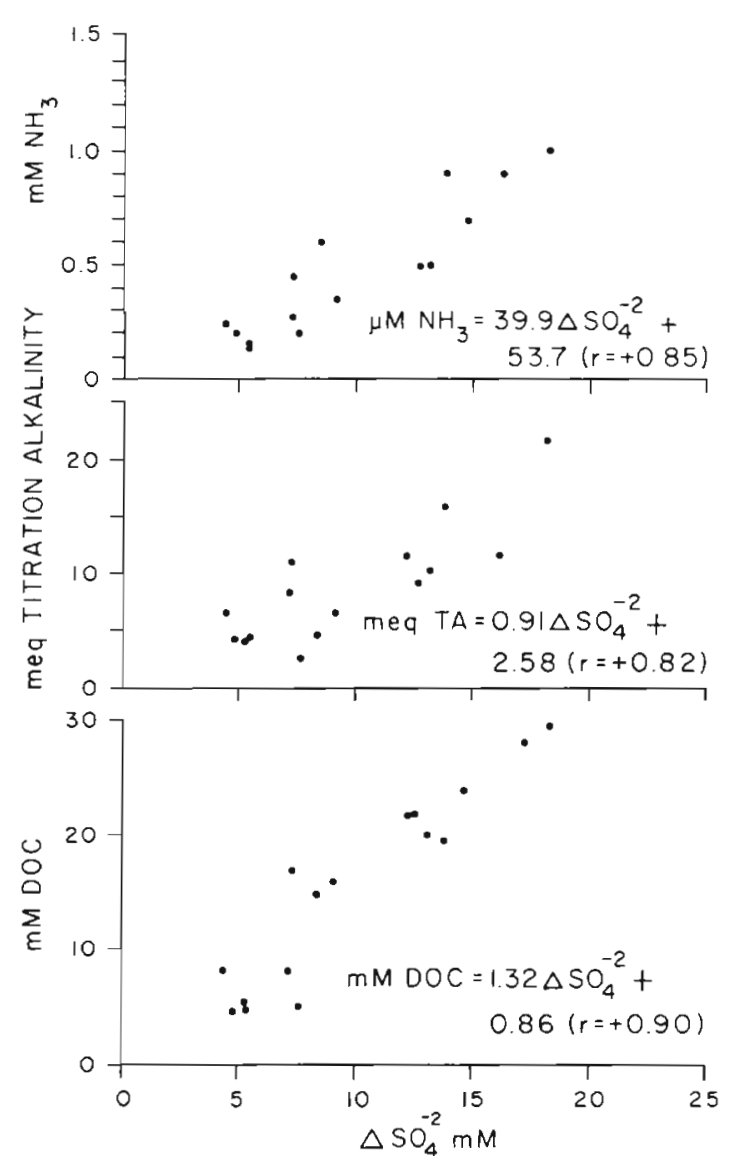

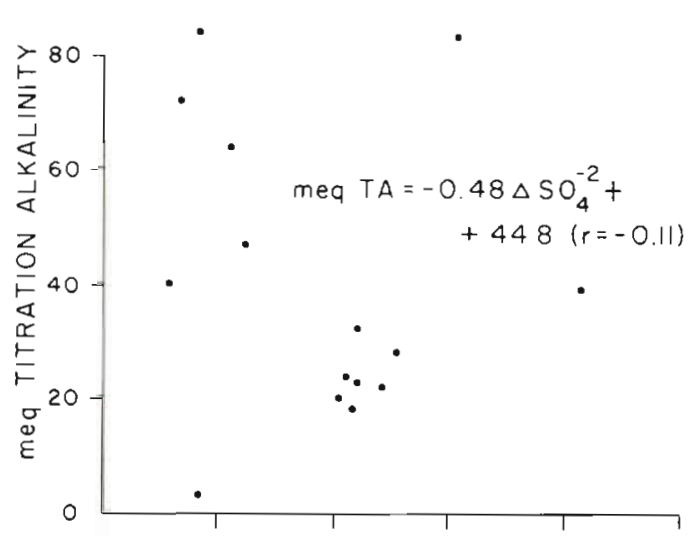

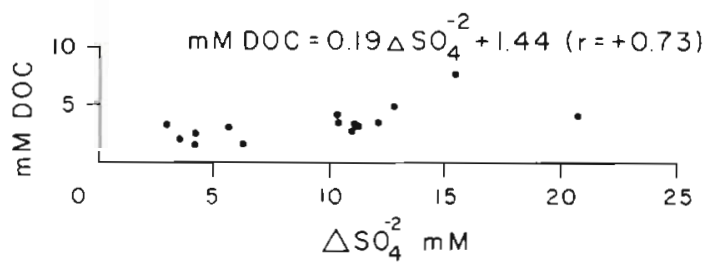

Fig. 2. Quiambog Cove pore-water chemistry. Relations plotted from data in Table 1 from April (left) and July (above)

Table 2. Biochemical INT and $\mathrm{O}_{2}$ reduction rates (nmol $2 \mathrm{e}^{-} \mathrm{cm}^{-3} \mathrm{~h}^{-1} ; \overline{\mathrm{X}} \pm 1 \mathrm{SD}$ ) from cores of Quiambog Cove muds obtained and incubated at in situ temperatures of $0,10,15$, and $20^{\circ} \mathrm{C}$. Calculated by subtracting the 5 min (at 15 and $20^{\circ} \mathrm{C}$ ) or $20 \mathrm{~min}$ (at 0 and $10^{\circ} \mathrm{C}$ ) reduction data. $\mathrm{O}_{2}$ data from simultaneous, parallel incubations of proportional slurries in $300 \mathrm{ml}$ biochemical oxygen demand (BOD) bottles $\pm 10 \mathrm{mM} \mathrm{NaN}_{3}$

\begin{tabular}{|c|c|c|c|c|c|c|c|}
\hline $\begin{array}{l}\text { Sediment } \\
\text { depth }(\mathrm{cm})\end{array}$ & $\begin{array}{l}0^{\circ} \mathrm{C} \\
\text { INT }\end{array}$ & $\begin{array}{l}10^{\circ} \mathrm{C} \\
\text { INT }\end{array}$ & $\begin{array}{l}15^{\circ} \mathrm{C} \\
\text { INT }\end{array}$ & $\begin{array}{c}15^{\circ} \mathrm{C} \\
\mathrm{O}_{2}\end{array}$ & $\begin{array}{l}20^{\circ} \mathrm{C} \\
\text { INT }\end{array}$ & $\begin{array}{c}20^{\circ} \mathrm{C} \\
\mathrm{O}_{2}\end{array}$ & $\begin{array}{l}\text { Depth mean } \\
\text { INT (SD) }\end{array}$ \\
\hline $0-1$ & 0 & 80 & 240 & 1300 & 300 & 2100 & 160 \\
\hline $1-2$ & 90 & 330 & 770 & 1400 & 200 & 1700 & $350 \quad(86)$ \\
\hline $2-4$ & 180 & 140 & 860 & 480 & 85 & 930 & $320(113)$ \\
\hline $4-6$ & 43 & 140 & 810 & 1300 & 520 & 1000 & $380 \quad(92)$ \\
\hline $6-8$ & 0 & 380 & 320 & 1600 & 200 & 810 & $230 \quad(74)$ \\
\hline \multicolumn{8}{|c|}{ Temperature } \\
\hline Mean & 52 & 210 & 600 & 1200 & 260 & 1300 & \\
\hline $\mathrm{SD}$ & 72 & 130 & 300 & 380 & 160 & 500 & \\
\hline
\end{tabular}

The highest rates of anoxic INT reduction occurred in the mid-sections of each of the $10 \mathrm{~cm}$ cores. Averages for the 1 to 2 and 4 to $6 \mathrm{~cm}$ layers were about twice those for the surface sediments. However, the 0 to $1 \mathrm{~cm}$ sediments had rates of $\mathrm{O}_{2}$ reduction as high as 2100 $\mathrm{nmol} \mathrm{cm}{ }^{-3} \mathrm{~h}^{-1}$ at $20^{\circ} \mathrm{C}(7$ times the surface layer INT rate) and $1300 \mathrm{nmol} \mathrm{O}$ (5 times the INT rate) at $15^{\circ} \mathrm{C}$. Also, at $15^{\circ} \mathrm{C}$, biochemical $\mathrm{O}_{2}$ reduction in the 4 to $8 \mathrm{~cm}$ layers was as great as or greater than the rates in the surface sediments.

Net community catabolic rates for the deeper sediments were calculated from the changes in the porewater samplers left undisturbed between April and July. After correction for diffusional fluxes (Berner 1980, Matson \& Brinson 1985), net rates were 20 to 50 $\mathrm{nmol} \mathrm{SO}{ }_{4}^{2-}, 11$ to $35 \mathrm{nmol} \mathrm{DOC}$, and 10 to $73 \mathrm{nmol} \mathrm{CO}$ 
(all units of $2 \mathrm{e}^{-} \mathrm{cm}^{-3} \mathrm{~h}^{-1}$ ). The latter 2 estimates assume the occurrence of organic carbon at oxidation state 0 (i.e. carbohydrate). The median of the $\mathrm{CO}_{2}$ rates, $42 \mathrm{nmol} 2 \mathrm{e}^{-} \mathrm{cm}^{-3} \mathrm{~h}^{-1}$, is (1) the same as the average $0{ }^{\circ} \mathrm{C}$ INT rates, and (2) about 9-fold lower than the average for the 1 to $5 \mathrm{~cm}$ layer, regardless of temperature.

\section{DISCUSSION}

Total microbial community activity in many sediments is difficult to measure because a variety of electron donors and acceptors is metabolized simultaneously. Adjacent microniches of heterotrophic and autotrophic activity commonly occur and produce a spatially and temporally variable redox regime (Vanderborght \& Billen 1975, Grundmanis \& Murray 1977, Jorgensen 1977, Oremland \& Taylor 1978, Hines \& Buck 1982, Jorgensen \& Revsbech 1985). To overcome this logistical problem and to study community metabolism from a common enzymic basis, variations of the electron transport system (ETS) method reported by Packard (1971) have been applied to both oxic and anoxic sediments (Weiser \& Zech 1975, Zimmerman 1975, Olanczuk-Neyman \& Vosjan 1977, Liu \& Strachan 1981, Matson 1982, 1985, Graf 1986, Peroni \& Rossi 1986). Although different alternate electron acceptors have been used (e.g. resazurin, several tetrazolium salts), all these techniques are conceptually similar to the methylene blue reduction indices used for decades in the health sciences to grade milk (Jay 1978). Tetrazolium salts interrupt electron transport by effectively competing with cytochromes (and not directly with the terminal electron acceptor) for electron pairs at sites specific for the particular tetrazolium salt, regardless of the character of the terminal electron acceptor (Altman 1976). They do not compete for $2 \mathrm{e}^{-}$pairs with the terminal electron acceptor, but with the enzymes within the ETS that facilitate $2 e^{-}$flow. Various aspects of tetrazolium reduction have been described previously (Kopper 1952, Eidus et al. 1959, Tengerdy et al. 1967, Kalina \& Palmer 1960, Saito \& Iwaizumi 1969, Anderson \& Hoyer 1974, Reichardt 1979, Smith \& Pugh 1979, Baker \& Mills 1982, Tabor \& Niehof 1982, Vosjan 1982).

Under anoxia, the 'in vivo' INT reduction technique used here measures all of $\mathrm{SO}_{4}^{2-}$ and $\mathrm{Fe}^{3+}$ reduction and a variable fraction of reduction of the other acceptors between $\mathrm{SO}_{4}^{2-}$ and $\mathrm{O}_{2}$ in the electrochemical gradient. During electron transport directed towards the reduction of sulfate or iron, any of the paired electrons that do not reduce a tetrazolium ion continue to the end of the respiratory chain and produce either $\mathrm{S}^{2-}$ or $\mathrm{Fe}^{2+}$, both of which reduce INT within seconds to minutes (Matson 1985). For all transport chains, the proportion of electron pairs that reduce an INT molecule (rather than the next enzyme in the transport chain) depends upon (1) the relative concentration of INT (a cation) bound to the procaryotic membranes, and (2) the rate of $2 e^{-}$flow through the pool of community ETS chains.

Under low concentrations of naturally occurring terminal electron acceptors (TEAs), the ETS is generally quite sensitive to both changes in TEA concentration (Doelle 1975, Mitchell 1979) and to potentially toxic chemicals such as INT (Fahmy \& Walsh 1952, Eidus et al. 1959, May et al. 1960, Slater et al. 1963, Clark et al. 1965). For example, with $\mathrm{O}_{2}$, INT begins to inhibit total electron flow (i.e. the reduction of both $\mathrm{O}_{2}$ and INT) only when the $\mathrm{INT} / \mathrm{O}_{2}$ ratio is greater than 0.3 (in units of $2 \mathrm{e}^{-}$; i.e. $100 \mu \mathrm{M}$ INT and $320 \mu \mathrm{M} \mathrm{O}_{2}$; Matson 1982 , 1985). This TEA stoichiometry should also apply to other TEAs such as $\mathrm{NO}_{3}^{-}, \mathrm{NO}_{2}^{-}$, and $\mathrm{Mn}^{4+}$. However, the reduced forms of these other TEAs (e.g. $\mathrm{NO}_{2}^{-}, \mathrm{NH}_{4}^{+}$, and $\mathrm{Mn}^{2+}$ ) do not reduce INT (as is the case for $\mathrm{S}$ and $\mathrm{Fe}$ ), and, under $\mathrm{N}_{2}$, reoxidation and subsequent recycling is precluded.

Further, in a few experiments with yeasts, fungi, diatoms, and nematodes, we observed INT reduction only after many hours to days, while active procaryotes reduce INT within minutes, depending upon temperature. This is apparently due to the extended length of time (at least hours) required for the tetrazolia to penetrate intact cells and to become exposed to fermentation dehydrogenases and to the mitochondria of eucaryotes (both of which, in contrast to the membrane-bound respiratory enzymes of procaryotes; are found in the cytoplasm; Haddock \& Jones 1977, Thauer et al. 1977). From this we tentatively conclude that the activity of fermenters (which may be important in the production of electron donors for sulfate-reducers; Sorensen et al. 1981, Howarth 1984) and of eucaryotes is not measured in this in vivo' INT assay. Also, no tetrazolia have been described that can be reduced at the pe of methanogenesis. These organisms may be quite numerous and active in some surface sediments (Oremland \& Taylor 1978, Hines \& Buck 1982). More importantly, the cytochrome chains of actively aerobic organisms collapse immediately (within seconds) and do not reduce INT when $\mathrm{O}_{2}$ is removed with $\mathrm{N}_{2}$, as in this assay (Matson 1985). For these reasons, the community catabolic data presented here are largely restricted to the activity of procaryotes that are actively respiring under $\mathrm{N}_{2}$ and in a regime of limited recycling of electron acceptors/donors, and therefore are underestimates.

A summary of cumulative oxic and anoxic community catabolism to $7 \mathrm{~cm}$ is given in Fig. 3. The total for INT reduction only is $207 \mathrm{~mol} 2 \mathrm{e}^{-} \mathrm{m}^{-2} \mathrm{yr}^{-1}$, or $86 \%$ of estimated total annual supply of OC to Quiambog Cove. If the $\mathrm{O}_{2}$ reduction data are used for the surface 


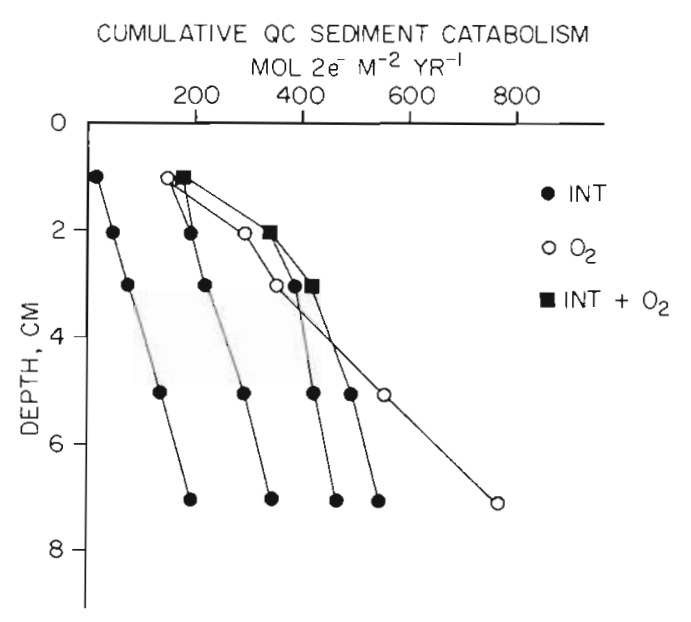

Fig. 3. Cumulative Quiambog Cove sediment catabolism. Depth averages for data in Table 2 integrated over the $7 \mathrm{~cm}$ sediment and extrapolated to annual rates

$1 \mathrm{~cm}$ and added to the 1 to $7 \mathrm{~cm}$ INT data, then the total is $308 \mathrm{~mol} 2 \mathrm{e}^{-} \mathrm{m}^{-2} \mathrm{yr}^{-1}$ or 1.3 times total OC supply. Organic matter contents of the subsurface muds to a depth of $7 \mathrm{~cm}$ average $5.5 \%$ or ca $320 \mathrm{~mol} \mathrm{OC} \mathrm{m}{ }^{-2}(640$ mol $2 \mathrm{e}^{-}$if it hypothetically exists as $\mathrm{CH}_{2} \mathrm{O}$, which it does not; Table 1) (Matson 1982). Therefore, in spite of the occurrence of anoxic catabolic rates that are approximately equivalent to total organic carbon supply, a substantial amount of $O C$ persists in these sediments.

Recently, Graf (1986) and Novitsky \& Karl (1986) mentioned the occurrence of high per-cell levels of subsurface microbial activity. These were considered anomalous in light of many reports of highest activity in the surface layer, either within or directly above the reductocline (Graf 1986). We suggest that the higher subsurface rates reported here for both $\mathrm{O}_{2}$ and INT are due to several factors. First, it is not surprising that anoxic INT reduction rates were higher below the reductocline. The incubation conditions under $\mathrm{N}_{2}$ inhibit the activity of obligate aerobes that may be a major component of the surface community. The higher $\mathrm{O}_{2}$ reduction rates in the 0 to $2 \mathrm{~cm}$ layers in comparison with anoxic INT rates support this conclusion. Also, more organic matter occurs in the top $1 \mathrm{~cm}(9.5 \%$ OC) than in the next $8 \mathrm{~cm}(5.5 \% \mathrm{OC})$. Thus it remains that facultatively anaerobic bacteria, some of which can simultaneously reduce $\mathrm{NO}_{3}^{-}$and $\mathrm{Fe}^{3+}$ (Thauer et al. 1977), are the active components of the subsurface community. These organisms, along with facultatively autotrophic chemolithotrophs, which may be responsible for the enrichments in $\mathrm{SO}_{4}^{2-}$, and which migrate in response to diel and seasonal redox regimes, probably dominate the procaryotic community structure. Further, anaerobes need to turn over more substrate than do aerobes in order to generate adenosine (ATP) triphosphate with their shorter electron transport chains. Indeed, the ratio of TEA reduced/ATP generated is substantially lower for anaerobes. With these considerations, it is easy to imagine situations in which a low bacterial biomass (and low rates of anabolism) could have very high rates of (catabolic) activity 'percell'. That anaerobes are 'inefficient' depends upon perspective.

Second, these phenomena are probably mediated by the hydrologic regime of Quiambog Cove. Presently, net sedimentation does not occur due to rapid historical accumulation within the cove up to the critical wave resuspension depth. The sediments can be described as soupy mud which are heavily bioturbated by softbodied infauna (especially holothurians such as Thyone spp.) and which are intermittently resuspended during storms (Matson 1982). Resulting episodic oxygenation, together with sufficient rates of anoxic metabolism that recharge the sediment with both methane and $\mathrm{S}^{2-}$ (and both occur within the top few cm; Hines \& Buck 1982) may maintain a 'euryoxic' milieu at this intermediate Eh (Bouleague \& Michaud 1979, Lord \& Church 1983). Periodic oxygenation may then resupply the sediment with oxidized TEAs (via either chemical or biochemical reoxidation) for facultatively anaerobic bacteria. After reduction, these reduced TEAs then become electron donors for chemolithotrophs and add to the recycled oxygen demand with electrons originally released during the decomposition of organic matter under anoxia. They also provide chemolithotrophs with the energy required to reduce respiratory pore-water $\mathrm{CO}_{2}$ back to organic matter. In this way, both carbon and energy are conserved under anoxia.

Perhaps this is why microbial cells in the environment may exhibit unbalanced growth, i.e., they may be capable of certain types of metabolism [catabolism] without a concomitant increase in biomass [anabolism].' (Novitsky \& Karl 1986, p. 34, contents of parentheses added). Biomass may remain relatively constant under a regime of switched community metabolism between heterotrophy (when labile $O C$ is abundant) and chemolithotrophy, when both $\mathrm{O}_{2}$ and the endproducts of anoxic heterotrophy (reduced TEAs and $\mathrm{CO}_{2}$ ) are abundant. The occurrence of prolific populations of chemolithotrophic bacteria, especially in winter and spring (Sorensen et al. 1979, Matson \& Brinson 1985, Graf 1986), may compound this paradox by adding organic matter to sediments via recycled $\mathrm{CO}_{2}$ and reduced TEAs. This 'coupled heterotrophy and autotrophy' (Kepkay \& Novitsky 1980) may also help explain why coastal systems apparently consume more than they produce. This coupling may also help explain the post-depositional persistence of organic matter in coastal sediments (e.g. Kepkay et al. 1979, Rowe \& Howarth 1985). 
Acknowledgements. This research was supported, in part, through the University of Connecticut Institute of Water Resources with federal funds from Grant A-069-CONN, Office of Water Resources. For assistance, we thank Pat Bubucis, Patsy Santaniello, Barbara McGill Grant, Mark Hines, Bob Degoursey, Mary Jane Spring, and Molly Hubbard. We also thank Mark Brinson, Bob Christian, Hans Paerl, Peter Rich, William Fitzgerald, Frank Bohlen, Sally Hornor, and 3 reviewers for helpful comments and suggestions. This is contribution No. 193 of the University of Connecticut Marine Research Laboratory, Noank, Connecticut.

\section{LITERATURE CITED}

Altman, F. P. (1976). Tetrazolium salts and formazans. Prog. Histochem. Cytochem. 9: 1-56

Anderson, H. Hoyer, P. E. (1974). Simplified control experiments in the histochemical study of coenzyme-linked dehydrogenases. Histochem. 38: 71-83

Baker, K. H., Mills, A. L. (1982). Determination of the number of respiring Thiobacillus ferroxidans cells in water samples by using combined fluorescent antibody -2-(p-iodophenyl)-3-( $p$-nitrophenyl)-5-phenyl tetrazolium chloride staining. Appl. environ. Microbiol. 43: 338-44

Berner, R. A. (1980). Early diagenesis: a theoretical approach. Princeton Univ. Press, Princeton, New Jersey

Bouleague, J., Michaud, G. (1979). Sulfur speciation and redox processes in reducing environments. In: Jenne, E. A. (ed.) Chemical modeling in aqueous systems. Am. Chem. Soc. Symp. Ser. 93, Washington, DC, p. 25-50

Clark, J. B., Greenbaum, A. L., Slater, T. F. (1965). Effects of tetrazolium salts on oxidative phosphorylation in rat liver mitochondria. Biochem. J. 94; 651-654

Cline, J. O. (1969). Spectrophotometric determination of hydrogen sulfide in natural waters. Limnol. Oceanogr. 14: $454-458$

Doelle, H. W. (1975). Bacterial metabolism. 2nd edn. Academic Press, New York

Eidus, L., Diena, B. B., Greenberg, L. (1959). Observations on the use of tetrazolium salts in the vital staining of bacteria. Can. J. Microbiol. 5: 245-250

Fahmy, A. R., Walsh, E. o'F. (1952). The quantitative determination of dehydrogenase activity in cell suspensions. Biochem. J. 51: 55--56

Foerster, J. W. (1973). The fate of freshwater algae entering an estuary. In: Stevenson, H. L., Colwell, R. R. (ed.) Estuarine microbial ecology. Univ. South Carolina Press, Columbia, p. $387-418$

Gerchakov, S. M., Hatcher, P. G. (1972). Improved technique for analysis of carbohydrates in sediments. Limnol. Oceanogr. 17: 938-943

Graf, G. (1986). Winter inversion of biomass and activity profile in a marine sediment. Mar. Ecol. Prog. Ser. 33: 231-235

Grundmanis, V., Murray, J. W. (1977). Nitrification and denitrification in marine sediments from Puget Sound. Limnol. Oceanogr. 22: 804-813

Haddock, B. A., Jones, C. W. (1977). Bacterial respiration. Bact. Rev. 41: 47-99

Hines, M. E., Buck, J. D. (1982). Distribution of methanogenic and sulfate-reducing bacteria in near-shore marine sediments. Appl. environ. Microbiol. 43: 447-453

Howarth, R. W. (1984). The ecological significance of sulfur in the energy dynamics of salt marsh and coastal marine sediments. Biogeochem. 1:5-27
Jay, J. M. (1978). Modern food microbiology. 2nd edn. D. Van Nostrand, New York

Jorgensen, B. B. (1977). Bacterial sulfate reduction within reduced microniches of oxidized marine sediments. Mar. Biol. 41: 7-17

Jorgensen, B. B., Revsbech, N. P. (1985). Diffusive boundary layers and the oxygen uptake of sediments and detritus. Limnol. Oceanogr 30: 111-122

Kalina, M., Palmer, J. M. (1960). The reduction of tetrazolium salts by plant mitochondrial. Histochem. 44: 366-74

Kepkay, P. E., Novitsky, J. A. (1980). Microbial control of organic carbon in marine sediments: coupled chemoautotrophy and heterotrophy. Mar. Biol. 55: 261-6

Kepkay, P. E., Cooke, R. C., Novitsky, J. A. (1979). Microbial autotrophy: a primary source of organic carbon in marine sediments. Science 204: 68-69

Kopper, P. H. (1952). Studies on bacterial reducing activities in relation to age of culture. J. Bacteriol. 63: 639-645

Liu, D., Strachan, W. M. J. (1981). A field method for determining the chemical and biological activity of sediments. Wat. Res. 15: 353-359

Lord, C. J. III, Church, T. M. (1983). The geochemistry of salt marshes: sedimentary ion diffusion, sulfate reduction, and pyritization. Geochim. Cosmochim. Acta 47: 1381-1391

Matson, E. A. (1982). The use of tetrazolium salts in studies of carbon and energy dynamics in anoxic sediments. Dissertation, Univ, of Connecticut, Storrs

Matson, E. A. (1985). Anoxic community catabolism in the shallow carbonate muds of Bermuda. Proc. 5th Int. Coral Reef Symp., Tahiti, Papeete, Vol. 3: 433-438

Matson, E. A., Brinson, M. M. (1985). Sulfate enrichments in estuarine waters of North Carolina. Estuaries 8: 279-289

May, P. S., Winter, J. W., Fried, G. H., Antopol, W. (1960). The effects of tetrazolium salts on selected bacterial species. Proc. Soc. Experim. Biol. Med. 105: 364-366

Mitchel, P. (1979). Keilin's respiratory chain concept and its chemiosmotic consequences. Science 206: 1148-1159

Novitshy, J. A., Kephkây, F. E. (1981). Patterins of microbial heterotrophy through changing environments in a marine sediment. Mar. Ecol. Prog. Ser. 4: 1-7

Novitsky, J. A., Karl, D. M. (1986). Characterization of microbial activity in the surface layers of a coastal subtropical sediment. Mar. Ecol. Prog. Ser. 28: 49-55

Olanczuk-Neyman, K. M., Vosjan, J. H. (1977). Measuring respiratory electron transport system activity in marine sediments. Neth. J. Sea Res. 11: 1-13

Oremland, R. S., Taylor, B. F. (1978). Sulfate reduction and methanogenesis in marine sediments. Geochim. Cosmochim. Acta 42: 209-214

Packard, T. T (1971). The measurement of respiratory electron transport systems in marine phytoplankton. J. mar. Res. 29: 235-244

Peroni, C., Rossi, G. (1986). Determination of microbial activity in marine sediments by resazurin reduction. In: Chemistry in ecology, Vol. 2. Gordon and Breach Science Publ., New York, p. 205-218

Reichardt, W. (1979). Significance of different methods to determine dehydrogenase (ETS) activities in aquatic environments. Arch. Hydrobiol. Beih. Ergeb. Limnol. 12: $105-114$

Rowe, G. T., Howarth, R. (1985). Early diagenesis of organic matter in sediments off the coast of Peru. Deep Sea Res. 32 : $43-55$

Saito, S., Iwaizumi, M. (1969). Free radical mechanism by which triphenyltetrazolium chloride stimulates aerobic oxidation of NADH by microsomes. Biochim. Biophys. Acta 172: $30-36$ 
Slater, T. F., Sawyer, B., Strauli, U. (1963). Studies on succinate-tetrazolium reductase systems: points of coupling of four different tetrazolium salts. Biochim. Biophys. Acta 77 383-393

Smith, S. N., Pugh, G. J. F. (1979). Evaluation of dehydrogenase as a suitable indicator of microbial activity. Enzyme and Microb. Technol. 1: 279-281

Sorensen, J., Jorgensen, B. B., Revsbech, N. P. (1979). A comparison of oxygen, nitrate, and sulfate respiration in coastal marine sediments. Microb. Ecol. 5: 105-115

Sorensen, J., Christensen, D., Jorgensen, B. B. (1981). Volatile fatty acids and hydrogen as substrates for sulfate-reducing bacteria in anaerobic marine sediment. Appl. environ. Microbiol. 42: 5-11

Tabor, P. S., Niehof, R. A. (1982). Improved method for determination of respiring individual microorganisms in natural waters. Appl. environ. Microbiol. 43: 1249-1255
Tengerdy, R. P., Nagy, J. G., Martin, B. (1967). Quantitative measurement of bacterial growth by the reduction of tetrazolium salts. Appl. Microbiol. 15: 954--955

Thauer, R. K., Jungerman, K., Decker, K. (1977). Energy conservation in chemotrophic anaerobic bacteria. Bact. Rev. 41: 100-180

Vanderborght, J. P., Billen, G. (1975). Vertical distribution of nitrate concentration in interstitial water of marine sediments with nitrification and denitrification. Limnol. Oceanogr. 20: 953-961

Vosjan, J. H. (1982). Respiratory electron transport system activities in marine environments. Hydrobiol. Bull. 16: 61-68

Weiser, W., Zech, M. (1975). Dehydrogenases as tools in the study of marine sediments. Mar. Biol. 36: 113-122

Zimmerman, A. P. (1975). Electron transport analysis as an indicator of biological oxidations in freshwater sediments. Verh. int. Verein. Limnol. 19; 1518-1523

This article was presented by Professor C. Birkeland; it was accepted for printing on August 18,1987 